\title{
Effect of High-dose Vitamin C Combined With Anti-cancer Treatment on Breast Cancer Cells
}

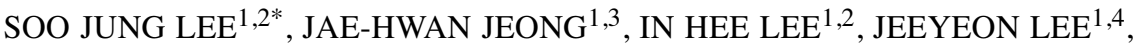 \\ JIN HYANG JUNG ${ }^{1,4}$, HO YONG PARK ${ }^{1,4}$, DUK HEE LEE ${ }^{5}$ and YEE SOO CHAE ${ }^{1,2}$ \\ ${ }^{1}$ School of Medicine, Kyungpook National University, Daegu, Republic of Korea; \\ Department of ${ }^{2}$ Oncology/Hematology, ${ }^{3}$ Cell and Matrix Research Institute, ${ }^{4}$ Breast and Thyroid Surgery, \\ Kyungpook National University Chilgok Hospital, Daegu, Republic of Korea; \\ ${ }^{5}$ Department of Preventative Medicine, School of Medicine, \\ Kyungpook National University, Daegu, Republic of Korea
}

\begin{abstract}
Background/Aim: The anti-cancer effect of high doses of intravenous vitamin $C$ (high-dose vitamin $C$ ) remains controversial despite growing evidence that highdose vitamin $C$ exerts anti-tumorigenic activity by increasing the amount of reactive oxygen species in cancer cells without meaningful toxicities. Therefore, this study attempted to demonstrate the in vitro anti-cancer activity of high-dose vitamin $C$ in combination with conventional treatment in breast cancer. Materials and Methods: The pro-apoptotic effects of high-dose vitamin C (1.25 to $20 \mathrm{mM})$ with or without anti-cancer agents (eribulin mesylate, tamoxifen, fulvestrant, or trastuzumab) were estimated using an MTT assay to measure the cell viability of a variety of breast cancer cell lines (MCF7, SK-BR3, and MDA-MB-231), as well as normal breast epithelial cells (MCF10A). Results: High-dose vitamin $C(\geq 10 \mathrm{mM})$ significantly decreased cell viability of all breast cancer cell lines, particularly of $M C F$ 7 cells. The catalase activities of MCF7 and MDA-MD-23I cells were also lower than those of MCF 10A cells. Moreover, cell viability of both MCF7 and MDA-MD-231 cells was decreased further when combining high-dose vitamin $C$ and eribulin mesylate, and this was also true for MCF-7 cells when combining high-dose vitamin $C$ with tamoxifen or fulvestrant and for SK-BR3 cells when combining high-dose
\end{abstract}

Correspondence to: Yee Soo Chae, Department of Oncology, Kyungpook National University Medical Center, Kyungpook National University School of Medicine, 807 Hogukno, Buk-Gu, Daegu, 702-210 Republic of Korea. Tel: +82 532002627, Fax: +82 532002029, e-mail: yschae@knu.ac.kr; or Ho Yong Park, Department of Surgery, Kyungpook National University Medical Center, Kyungpook National University School of Medicine, 807 Hogukno, Buk-Gu, Daegu, 702-210 Republic of Korea. Tel: +82 532003521, Fax: +82 532002029, e-mail: phy123@knu.ac.kr

Key Words: High-dose vitamin C, breast cancer, anticancer effect. vitamin $C$ with trastuzumab in comparison with chemotherapy or endocrine therapy alone. Conclusion: Combining high-dose vitamin $C$ with conventional anticancer drugs can have therapeutic advantages against breast cancer cells.

Breast cancer is the most commonly diagnosed type of cancer and the second leading cause of cancer-related death in women worldwide (1). Despite advances in early detection and systemic treatment, including cytotoxic, hormonal, and biological agents based on understanding breast cancer biology, about $30 \%$ of patients experience recurrent disease after curative surgery. Also, advanced breast cancer (ABC) patients ultimately progress within 1 or 2 years, regardless of their response to treatment, and the response to subsequent agents is generally lower (2). While the ability of biological or targeted agents to improve the efficacy and overcome resistance to conventional agents has been explored in a variety of cancers, there are still important obstacles related to tumor specificity and cost. As a result, many patients, especially in Asia, are actively considering alternative or supplementary medicines to conventional therapies, especially antioxidants such as vitamin $\mathrm{C}$, despite a lack of definitive evidence (3).

However, there is growing evidence that high (pharmacologic) concentrations of vitamin $\mathrm{C}$ induce dosedependent pro-apoptotic death of tumor cells in vitro $(4,5)$. While minimal data are available for breast cancer, vitamin $\mathrm{C}$ has been frequently reported to induce apoptosis in human breast cancer cells without having a significant impact on normal cells (6-8), for example, through the nuclear translocation of an apoptosis-inducing factor (AIF) (9). Furthermore, biological evidence also suggests that high extracellular or tissue concentrations of vitamin $\mathrm{C}$ can reduce the toxicity of chemotherapy (10). Interestingly, pharmaco-kinetic studies have reported that $10 \mathrm{~g}$ of vitamin 
$\mathrm{C}$, equal to a $6 \mathrm{mM}$ plasma concentration, is toxic to cancer cells in vitro (1-10 $\mathrm{mM}$, depending on the cell line) (11, 12), suggesting that vitamin $C$ may function as a prooxidant at a high plasma concentration, while ascorbate behaves as an antioxidant at a low or physiological dose $(6$, 11). In addition, since tumor tissue often lacks blood flow and antioxidant enzymes, such as catalase, the formed $\mathrm{H}_{2} \mathrm{O}_{2}$ remains active, leading to cancer cell damage and death (13).

Notwithstanding, limited data are available on the use of high-dose vitamin $C$ in breast cancer, even though vitamin $C$ is frequently used as a supplement without considering the plasma concentration. Accordingly, the current study explored the anticancer effect of high-dose vitamin $\mathrm{C}$ on breast cancer cells, alone or in combination with anticancer agents.

\section{Materials and Methods}

Cell lines. The breast epithelial cell line MCF10A and breast cancer cell lines MDA-MB-231, MCF-7, and SK-BR-3 were purchased from the American Type Culture Collection (ATCC). MCF10A was maintained in a Dulbecco's Modified Eagle's Media (DMEM)/F12 (1:1) medium (Lonza, Walkersville, MD, USA) supplemented with $10 \%$ fetal bovine serum (FBS; Gibco, Grand Island, NY, USA), $10 \mathrm{ng} / \mathrm{ml}$ epidermal growth factor, $0.5 \mu \mathrm{g} / \mathrm{ml}$ hydrocortisone, $100 \mathrm{ng} / \mathrm{ml}$ cholera toxin, and $10 \mu \mathrm{g} / \mathrm{ml}$ insulin. MDA-MB-231, MCF-7 and SK-BR-3 were all grown in DMEM (Gibco) supplemented with $10 \%$ FBS. The tamoxifen-resistant MCF-7 cells (TRAM-R) and long-term estrogen-deprived MCF-7 cells (LTED) were provided by Dr. Richard J. Santen (University of Virginia, USA). The TRAM-R cells were continuously maintained in DMEM containing $10 \%$ FBS and $10-7 \mathrm{~mol} / 1$ tamoxifen, while the LTED cells were maintained in phenol-red-free DMEM containing $5 \%$ charcoal-dextran-stripped FBS.

Materials. Tamoxifen and Faslodex (ICI 182,780) were purchased from Sigma-Aldrich (St. Louis, MI, USA) and Abcam plc (Cambridge CB4 OFL, UK), respectively. Eribulin mesylate (Halaven ${ }^{\circledR}$, Eisai Inc., Tokyo, Japan), ascorbic acid (Bio Chemical R\&D, Gyeounggi-do, Korea), trastuzumab $\left(\right.$ Herceptin $^{\circledR}$, Roche Diagnostics, Basel, Switzerland), paclitaxel (Genexol ${ }^{\circledR}$, Samyang Biopharm, Daejeon, Korea), and doxorubicin hydrochloride (A.D.mycin ${ }^{\circledR}$, Boryung co., Gyeonggi-do, Korea) were all kindly provided.

Cell apoptosis assay. The cells were seeded in 48-well plates at a density of $2 \times 10^{4}$ cells per well. After culture for $24 \mathrm{~h}$, cells were washed with PBS, medium was changed and cells were exposed to vitamin $\mathrm{C}$ for $4 \mathrm{~h}$. Next, plates were centrifuged, the medium was removed and apoptotic cell death was determined using Cell Death Detection ELISAPLUS kit (Roche, Mannheim, Germany) according to the manufacturer's instructions. Briefly, after lysis and centrifugation, cell lysates were incubated with biotin-labelled antihistone and with peroxidase-conjugated antibodies to DNA in a streptavidin-coated microtiter plate for $2 \mathrm{~h}$ at room temperature. After incubation, peroxidase substrate was added, the plate was incubated at room temperature for about $15 \mathrm{~min}$ and the peroxidase activity was determined by ELISA reader at a detection wavelength of $405 \mathrm{~nm}$ and $490 \mathrm{~nm}$.

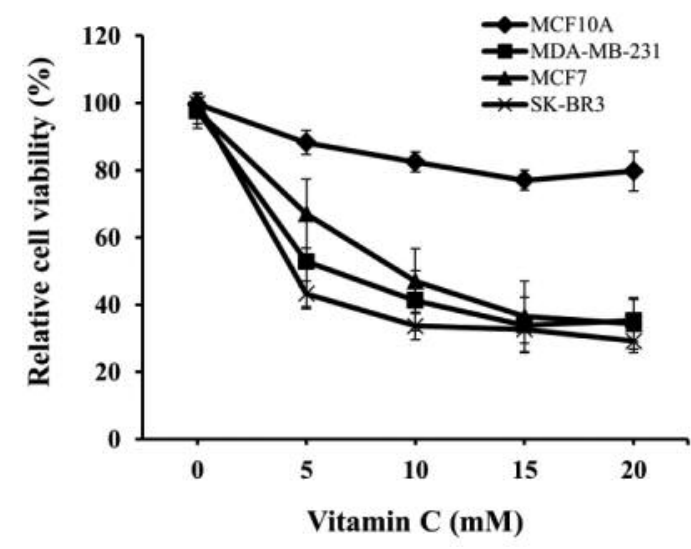

Figure 1. Effects of pharmacological dose of vitamin C on human breast cancer cell lines. High-dose vitamin $C$ suppressed proliferation of breast cancer cell lines (MDA-MB-231, MCF-7, and SK-BR3), but not normal cells (MCF10A).

Detection of catalase activity. It has been suggested that the anticancer effect of vitamin $\mathrm{C}$ is due to the accumulation of $\mathrm{H}_{2} \mathrm{O}_{2}$ due to the insufficiency of catalase in cancer cells (14). Therefore, the catalase activity in each breast cancer cell line was measured using a Catalase Assay Kit (Cayman, MI, USA) following the manufacturer's instructions and compared with the catalase activity in the normal breast epithelial cell line (MCF10A). The catalase activity was calculated by normalization with the total protein amount in the lysates. The protein concentration was estimated using a Bradford Protein Assay Kit (Bio-Rad, CA, USA). The experiment was repeated three times and the data presented are the means \pm S.D.

Cell viability assay. The high-dose vitamin C-induced cell death in the breast cell lines was quantified using a cell viability assay. The cells were plated in 48 -well plates at a cell density of $2 \times 10^{4}$ per well. After culturing overnight, the cells were exposed to vitamin $\mathrm{C}$ for $2 \mathrm{~h}$, washed with phosphate buffered saline (PBS), and cultured for an additional $24 \mathrm{~h}$ in a growth medium with ascorbic acid.

To explore the combined effect of anti-cancer agents and vitamin C, the cells were plated $2 \times 10^{4}$ per well in 48 -well tissue culture plates and allowed to attach overnight. The cells were then treated with an anti-cancer agent for $24 \mathrm{~h}$, treated with vitamin $\mathrm{C}$ for $2 \mathrm{~h}$, washed and cultured for additional $24 \mathrm{~h}$, or treated with vitamin $\mathrm{C}$ for $2 \mathrm{~h}$ on consecutive days, washed and cultured for additional $24 \mathrm{~h}$ after each exposure.

Cell proliferation was estimated using an MTT assay. Briefly, $200 \mu \mathrm{l}$ of MTT solution $(2 \mathrm{mg} / \mathrm{ml}$ ) were added to cells for $4 \mathrm{~h}$. After removing the MTT solution, $400 \mu$ of dimethyl sulfoxide (DMSO) were added to cells. The optical density was then measured at $540 \mathrm{~nm}$ using an absorbance reader (BioTek Instruments Inc., Winooski, VT, USA).

Statistical analysis. Data was expressed as the mean \pm standard deviation (SD) of three or more independent experiments. Differences between two groups were evaluated using the Student's $\mathrm{t}$ test. Results were considered significant at $p<0.05$. 
MCF-10A

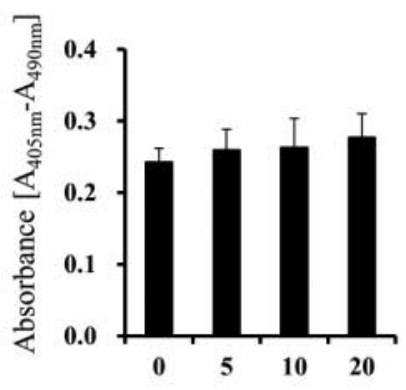

Ascorbic acid $(\mathrm{mM})$
MDA-MB-231

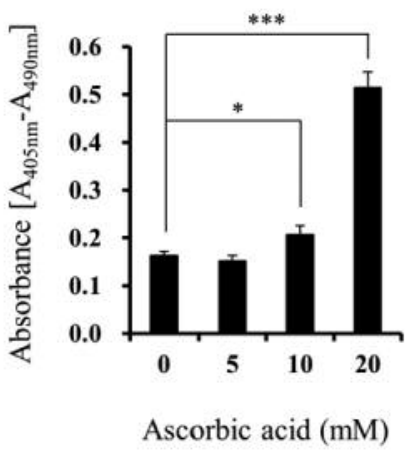

MCF-7

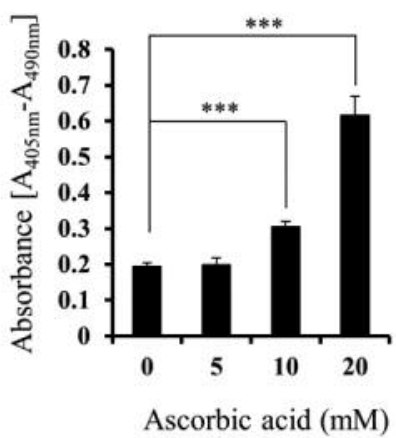

Figure 2. High-dose vitamin $C$ induces apoptosis of breast cancer cells. $* p<0.01 ; * * * p<0.001$.

\section{Results}

High-dose vitamin C inhibited proliferation of breast cancer cells, yet not normal cells. First, the effects of high-dose vitamin $\mathrm{C}$ on breast cancer cell lines (MDA-MB-231, MCF-7, and SK-BR-3) and a normal breast epithelial cell line (MCF10A) were determined. As shown in Figure 1, high-dose vitamin $\mathrm{C}$ inhibited the cell growth of various breast cancer cells in a dose-dependent manner, represented by the relative cell viability after treatment with $5,10,15$ and $20 \mathrm{mM}$ vitamin C: $52.8 \pm 14.1 \%, 41.2 \pm 8.9 \%, 34.0 \pm 8.3 \%$, and $35.3 \pm 6.3 \%$ in MDA-MB-231, 67.1 $\pm 10.3 \%, 47.0 \pm 9.7 \%$, $36.5 \pm 10.5 \%$, and $34.4 \pm 7.6 \%$ in $\mathrm{MCF}-7,43.2 \pm 3.8 \%$, $33.7 \pm 4.0 \%, 32.7 \pm 4.1 \%$, and $29.1 \pm 3.4 \%$ in SK-BR-3, respectively. In contrast, minimal inhibition was observed in the normal breast epithelial cell line, MCF10A following treatment with high-dose vitamin $\mathrm{C}$.

High dose vitamin $C$ induced apoptosis of breast cancer cells. To determine the effect of high dose vitamin $\mathrm{C}$ on the viability of breast cancer cells, an apoptosis assay, based on nuclear changes such as DNA fragmentation, was performed. High Vitamin C concentrations $(10 \mathrm{mM}$ or $20 \mathrm{mM})$ caused apoptosis of breast cancer cell lines, MDA-MB-231 and MCF-7 (Figure 2). However, this apoptosis-inducing effect was reduced in MCF10A cells. These results suggest that high dose vitamin $\mathrm{C}$ has a selective apoptotic effect in breast cancer cells.

Combination of high-dose vitamin $C$ and anti-cancer drugs had an additional inhibitory effect on the growth of breast cancer cell lines. Next, it was determined whether the combination of high-dose vitamin $\mathrm{C}$ and anti-cancer drugs could induce growth inhibition of breast cancer cells. After treatment with eribulin mesylate for $24 \mathrm{~h}$, the cells were exposed once (Figure 3A and C) or twice (Figure 3B and D) to various concentrations of vitamin $\mathrm{C}(5,10$, and $20 \mathrm{mM})$. As shown in Figure 3A, one treatment with vitamin $\mathrm{C}$ did not significantly increase the efficacy of eribulin mesylate to inhibit growth of MDA-MB-231cells. However, two treatments with vitamin $\mathrm{C}$ produced a marked decrease in the cell viability of MDA-MB-231 cells when compared to eribulin mesylate alone, $(18.2 \pm 2.5 \%$ with $1.25 \mathrm{nM}$ eribulin mesylate plus $20 \mathrm{mM}$ vitamin C, $44.7 \pm 2.8 \%$ with $1.25 \mathrm{nM}$ eribulin mesylate) in a dose-dependent manner. Similarly, MCF-7 cell growth was dramatically inhibited by high-dose vitamin $\mathrm{C}$ combined with eribulin mesylate (Figure $3 \mathrm{C}, \mathrm{D}$ ). The effect of combination of vitamin $\mathrm{C}$ with selected estrogen receptor modulators (SERMs), such as tamoxifen or fulvestrant, in MCF-7 cells was similar to that of eribulin (Figures 4 and 5). For example, the relative cell viability of MCF-7 cells was significantly decreased when combining tamoxifen and two treatments of vitamin $\mathrm{C}$ in a dosedependent manner $(13.6 \pm 2.5 \%$ vs. $60.2 \pm 6.1 \%$ with $4 \mu \mathrm{M}$ tamoxifen $+2 \times 20 \mathrm{mM}$ vitamin $\mathrm{C}$ and $4 \mu \mathrm{M}$ tamoxifen alone, respectively, Figure 4B). In the case of fulvestrant, an additive anti-proliferative effect was observed with one treatment of vitamin $C$, yet not with two (Figure 5). Notwithstanding, a dose-dependent inhibitory effect of vitamin C was found with both SERMs in MCF-7 cells.

When combined with trastuzumab, vitamin $\mathrm{C}$ significantly inhibited SK-BR-3 cell proliferation compared to trastuzumab alone (Figure 6). However, unlike MCF-7, no dose-dependent effect of vitamin $\mathrm{C}$ combined with trastuzumab was found in SK-BR-3 cells.

When taken together, the combined treatment with highdose vitamin $\mathrm{C}$ and anti-cancer agents did further facilitate anti-tumor activity towards breast cancer cells relative to the single agent. Thus, the results indicate that high-dose vitamin $\mathrm{C}$ can be a useful adjunctive agent with a variety of anticancer drugs for managing different types of breast cancer with minimal damage to normal cells. 
A

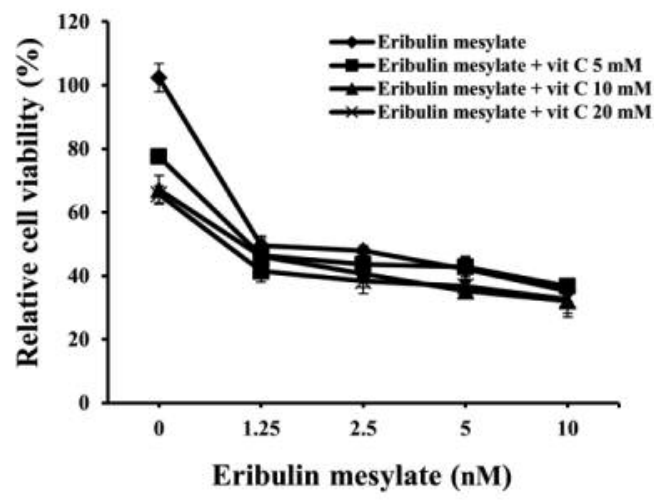

$\mathrm{C}$

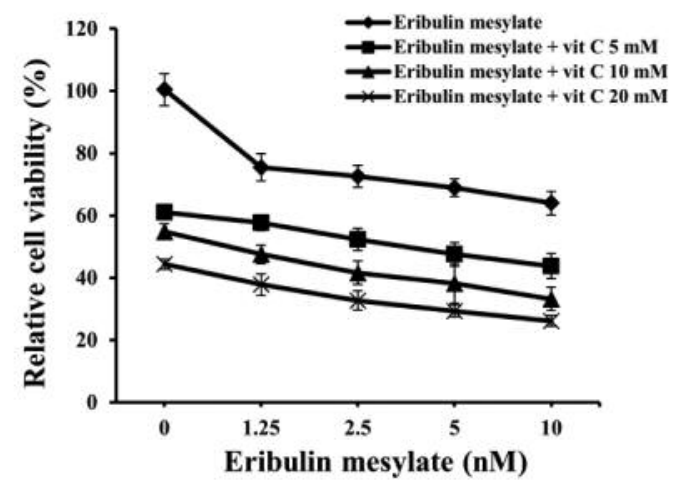

B

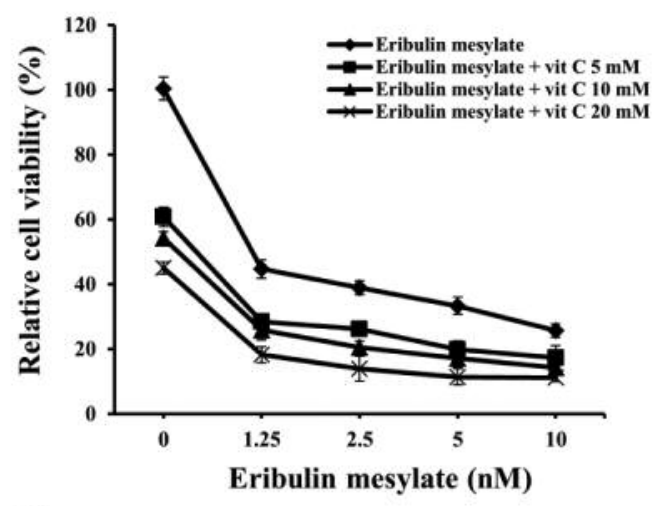

$\mathrm{D}$

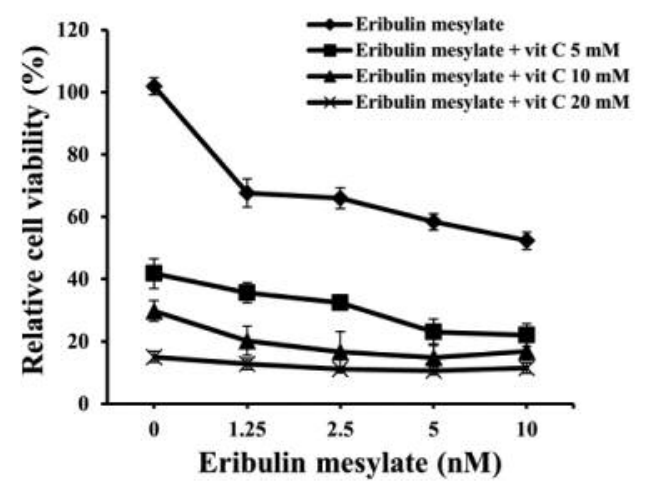

Figure 3. Combination of high-dose vitamin $C$ and anti-cancer drugs has an additional inhibitory effect on growth of breast cancer cell lines. After treatment with eribulin mesylate for $24 \mathrm{~h}$, the cells were exposed once $(A, C)$ or twice $(B, D)$ to various concentrations of vitamin $C(5,10$, and $20 \mathrm{mM})$.

High-dose vitamin $C$ had anti-proliferation effect on anticancer-drug-resistant cells. The high-dose vitamin Cmediated anti-proliferative effects on various anticancerdrug-resistant cell lines were also evaluated, including tamoxifen-resistant (TAM-R) MCF-7, LTED MCF-7, docetaxel-resistant MCF-7 and MDA-MB-231, and doxorubicin-resistant MCF-7 and MDA-MB-231 cells. Highdose vitamin $\mathrm{C}$ significantly inhibited the cell growth of TAM-R, doxorubicin-resistant MCF-7 and LTED MCF-7, as effectively as that of MCF-7 cells (Figure 7A). Moreover, vitamin $\mathrm{C}$ only exerted a slight effect on the normal breast epithelial cells, MCF10A (Figure 7A). In addition, antiproliferative effects of high-dose vitamin $\mathrm{C}$ were also observed in doxorubicin-resistant MDA-MB-231 cells and docetaxel-resistant MCF-7 cells, as effectively as in MDAMB-231 cells (Figure 7B). Furthermore, the catalase activity of TAM-R MCF-7, LTED MCF-7, docetaxel-resistant MCF7 and MDA-MB-231, and doxorubicin-resistant MCF-7 cells was significantly decreased compared to that of MCF10A cells (Figure 7). Therefore, these results indicate that highdose vitamin $\mathrm{C}$ has a selective anti-proliferative effect on chemotherapy-resistant breast cancer cells.
Catalase activity in breast cancer cells. It has been reported that the antitumor effects of vitamin $\mathrm{C}$ are mediated to the accumulation of $\mathrm{H}_{2} \mathrm{O}_{2}$ due to the insufficiency of catalase in cancer cells. To confirm the deficiency of catalase activity in cancer cells, catalase activity was measured in breast cancer cells. Interestingly, the catalase activity of MDA-MD-231 and MCF-7 cells was significantly decreased compared to that of MCF10A cells $(0.45 \pm 0.09$ and $0.35 \pm 0.18 v s$. $0.90 \pm 0.29 \mathrm{nmol} / \mathrm{min} / \mathrm{ml} / \mu \mathrm{g}$ of protein, respectively, Figure 8). In addition, low catalase activity was also observed in drug resistant breast cell lines, TAM-R, LTED MCF-7, docetaxel-resistant MCF-7 and MDA-MB-231, and doxorubicin-resistant MCF-7 and MDA-MB-231 cells (Figure 8). These results may indicate that high-dose vitamin $\mathrm{C}$ exerts a selective anti-proliferative effect on breast cancer cells with a low catalase activity.

\section{Discussion}

Based on previous reports, high-dose vitamin $\mathrm{C}$ exerts antitumorigenic activity by increasing the amount of reactive oxygen species (ROS) in cancer cells without meaningful 
A

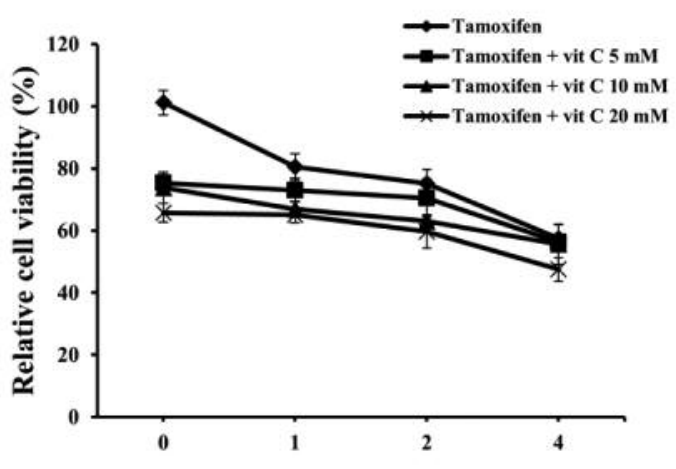

Tamoxifen $(\mu \mathrm{M})$
B

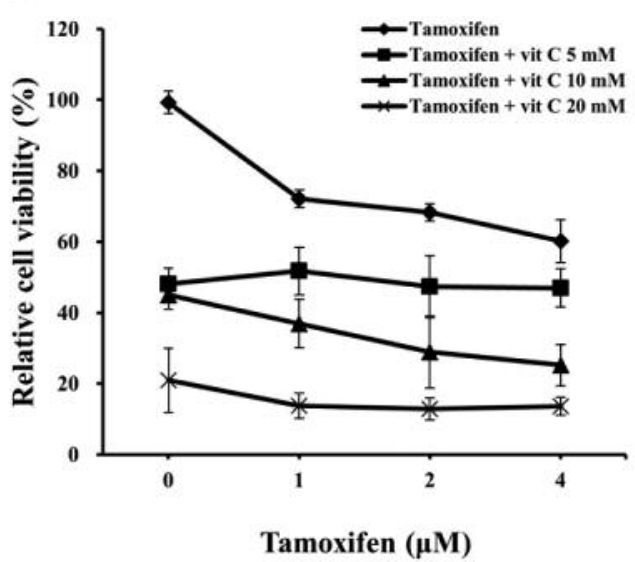

Figure 4. Combination effect of vitamin $C$ with tamoxifen in MCF-7. After treatment with tamoxifen for 24 h, the cells were exposed once (A) or twice (B) to various concentrations of vitamin $C(5,10$, and $20 \mathrm{mM})$. The relative cell viability of MCF-7 was significantly decreased when combining tamoxifen and two treatments of vitamin $C$ in a dose-dependent manner for vitamin $C(B)$.

A

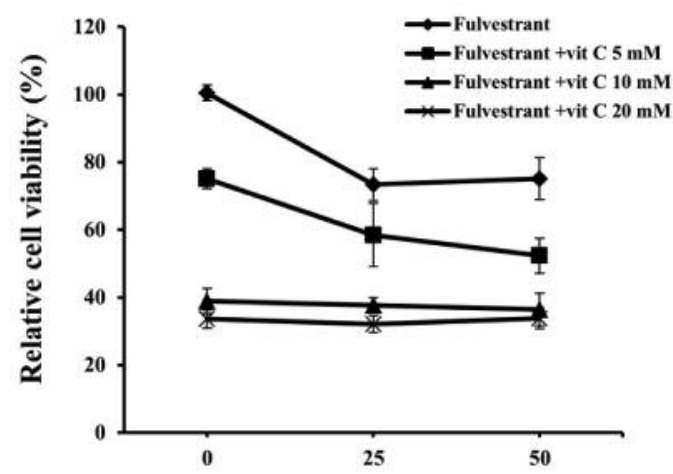

Fulvestrant $(\mu \mathrm{M})$
B

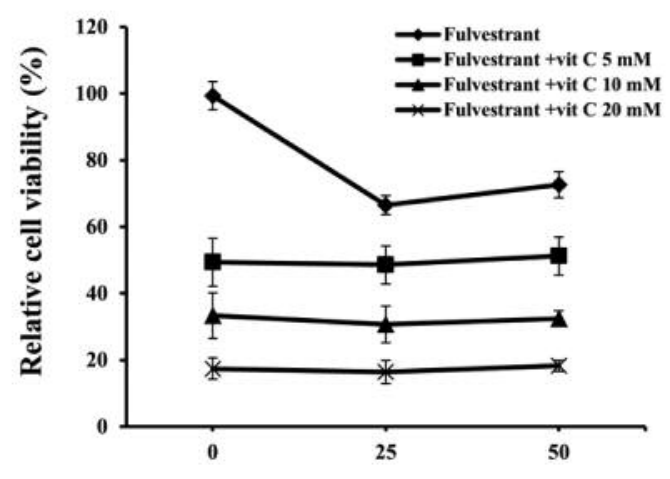

Fulvestrant $(\mu \mathrm{M})$

Figure 5. Combination effect of vitamin C with fulvestrant in MCF-7. After treatment with fulvestrabt for 24 h, the cells were exposed once (A) or twice $(B)$ to various concentrations of vitamin $C(5,10$, and $20 \mathrm{mM})$. An additive anti-proliferative effect was observed with one treatment of vitamin $C(A)$, yet not two $(B)$.

toxicities in normal cells, the current study aimed to demonstrate the in vitro anti-cancer activity of high-dose vitamin $\mathrm{C}$ and high-dose vitamin $\mathrm{C}$ combined with conventional treatment of breast cancer. As expected, the catalase activity in MDA-MD-231 and MCF-7 cells was lower than that in MCF10A cells. High-dose vitamin C suppressed the proliferation of MDA-MB-231, MCF-7, and SK-BR3 cells, yet not that of the normal breast cells (MCF10A). The combination of anti-cancer drugs with highdose vitamin $\mathrm{C}$ showed a stronger inhibition of the proliferation of breast cancer cells than a single anti-cancer drug. Moreover, high-dose vitamin $\mathrm{C}$ also inhibited the cell growth of tamoxifen-, doxorubicin-, and docetaxel-resistant MCF-7 cells. Therefore, these findings indicate that highdose vitamin $\mathrm{C}$ is a promising anti-cancer drug for breast cancer, without meaningful toxicity.

Vitamin $\mathrm{C}$ is an antioxidant at a conventional dose, exerting a protective role for normal cells against toxic compounds. Cancer therapy can produce ROS, which attack healthy cells and tissues, thereby leading to further damage and unintended side effects (15). An increased uptake and metabolism of glucose are characteristic of a malignant 
A

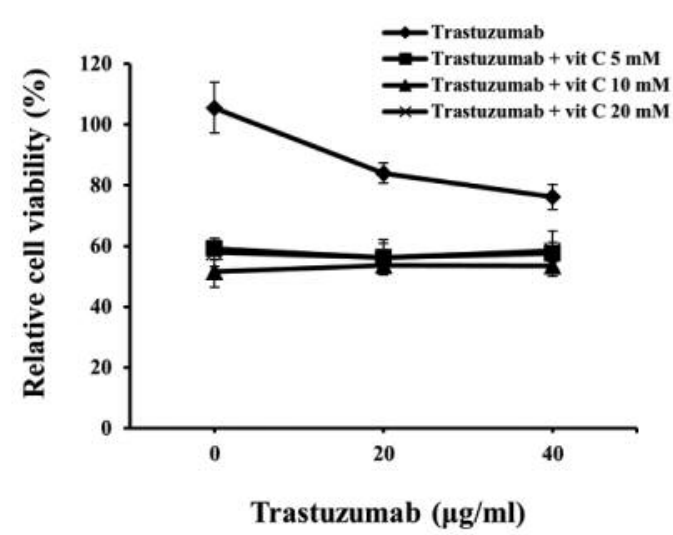

B

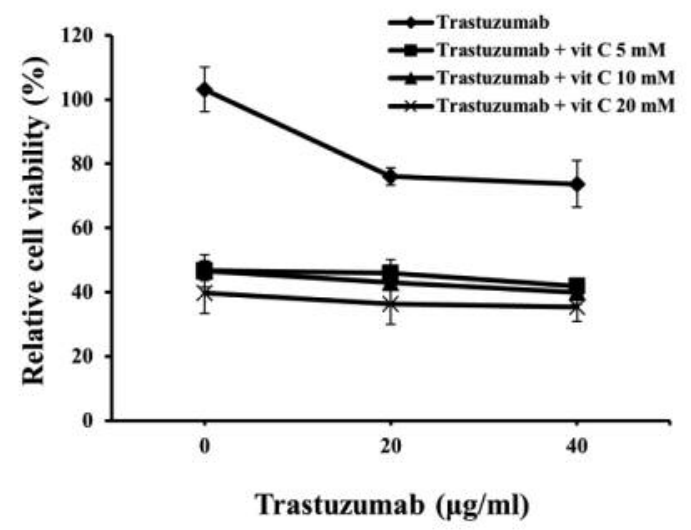

Figure 6. Combination effect of vitamin C with trastuzumab in SK-BR3. The relative cell viability of SK-BR3 was significantly decreased when combining trastuzumab and one $(A)$ or two $(B)$ treatments of vitamin $C$ without a dose-dependent effect.

\section{A. MCF7}

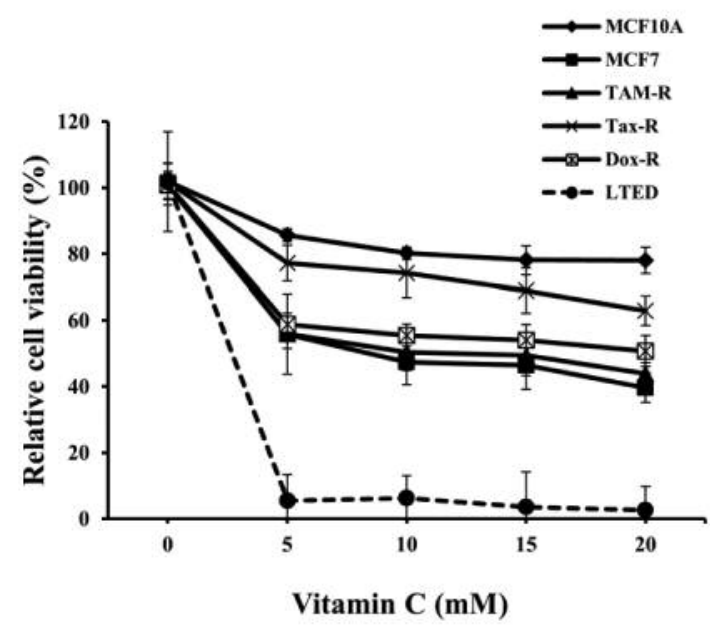

B. MDA-MB-231

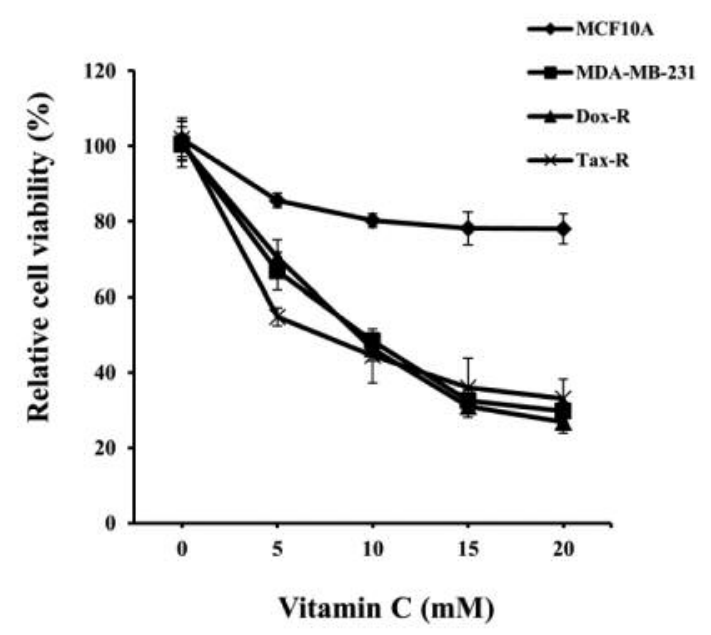

Figure 7. High-dose vitamin $C$ mediated an anti-proliferative effect on various anti-cancer-drug-resistant cells (tamoxifen-resistant (TAM-R) MCF-7, LTED MCF-7, docetaxel-resistant (Tax-R) MCF-7 and MDA-MB-231, and doxorubicin-resistant (Dox-R) MCF-7 and MDA-MB-231 cells. (A) Highdose vitamin $C$ significantly inhibited the cell growth of TAM-R, Dox-R MCF-7 and LTED MCF-7 as effectively as MCF-7; (B) Anti-proliferative effects of high-dose vitamin $C$ were also observed in Dox-R MDA-MB-231 and Tax-R MDA-MB-231, as effectively as in MDA-MB-231.

transformation and the overexpression of glucose transporters is a common event in malignancies. Therefore, tumor cells can accumulate more vitamin $\mathrm{C}$ than normal cells via glucose transporters (GLUTs), protecting them against the negative effects of $\operatorname{ROS}(15,16)$. Thus, in clinical practice, vitamin $\mathrm{C}$ has been commonly used with chemotherapy based on its protective effect for normal cells.

However, at pharmacological concentrations, vitamin $\mathrm{C}$ has pro-oxidant properties by preferentially accumulating in tumors and reducing redox-active metals (17) and catalase activity, and thereby maintaining cytotoxic levels of hydrogen peroxide that kills cancer cells $(18,19)$. Similarly, the current experimental results showed that high-dose vitamin $\mathrm{C}$ inhibits the proliferation of breast cancer cells and particularly treatment-resistant breast cancer cells, yet not that of normal cells. One possible in vitro antitumor mechanism is that vitamin $\mathrm{C}$ enhances the ability of cancer cells to absorb and accumulate high levels of iron in tumors, leading to the production of hydrogen peroxide $\left(\mathrm{H}_{2} \mathrm{O}_{2}\right)$, which is a potent pro-oxidant, capable of causing free radical cell damage. 


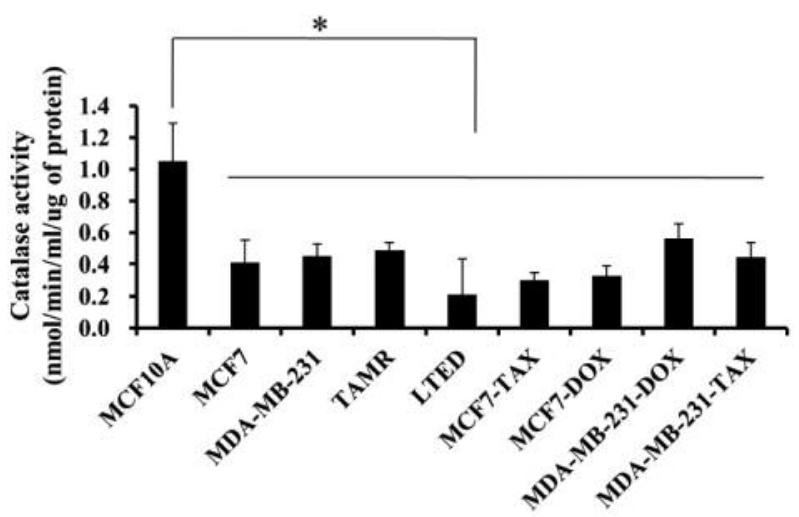

Figure 8. Catalase activity in breast cancer cells showed a reduction compared to MCF10A cells. The catalase activity of TAM-R MCF-7, LTED MCF-7, docetaxel-resistant MCF-7 and MDA-MB-231, and doxorubicin-resistant MCF-7 was significantly lowered compared to that of MCF10A. * $p<0.01$.

While normal cells have sufficient catalase to disable $\mathrm{H}_{2} \mathrm{O}_{2}$, cancer cells selectively absorbing vitamin $\mathrm{C}$ have lower catalase activity and therefore, accumulate higher levels of $\mathrm{H}_{2} \mathrm{O}_{2}$ than normal cells and their vulnerability increases.

Thus, the concept of high-dose vitamin $\mathrm{C}$ therapy has been adopted in cancer treatment to gain sufficient vitamin $\mathrm{C}$ concentrations for cancer cell toxicity, thus providing a pharmacological advantage (11). For example, high-dose intravenous vitamin $\mathrm{C}$ therapy has already been shown to effectively reduce the progression of malignant tumors and improved the health status of advanced cancer patients (20). Thereafter, several trials have also explored the clinical benefits of combining vitamin $\mathrm{C}$ with chemotherapy in various cancers (21-23), although not all studies have shown positive results.

One possible explanation for inconsistent results is determining the optimal concentration of high-dose vitamin $\mathrm{C}$ to achieve the maximal cancer cell killing effect. It is likely that higher plasma concentrations were achieved in Cameron and Pauling's studies $(24,25)$, which used both intravenous and oral administrations, in contrast to Moertal et al.'s studies $(4,5)$, who only used oral administration, which in turn may have contributed to the discrepancies in the therapeutic outcomes. The current study also showed that the plasma concentration for a vitamin-C cytotoxic effect in cancer cells was 1-10 mM. In addition, Choi et al. recently reported that intravenous administration of high-dose vitamin C $(1 \mathrm{~g} / \mathrm{kg})$ after surgery significantly reduced the recurrence rate $(6.94 \%$ $v s .18 .75 \%, p$-value $=0.028)$ in early breast cancer patients.

This study also showed additional anti-tumor activity when combining high-dose vitamin $\mathrm{C}$ with conventional treatment. The combination of high-dose vitamin $\mathrm{C}$ and anticancer drugs showed an additional inhibition effect on the proliferation of breast cancer cells over a single anti-cancer drug in a dose-dependent manner, which is consistent with previous reports of a synergistic or additive tumoricidal action of vitamin $\mathrm{C}$ with a variety of anti-cancer drugs (23, 26, 27). Therefore, these consistent results provide strong evidence that high-dose vitamin $\mathrm{C}$ potentiates the therapeutic effect of different chemotherapy agents (28). Moreover, the additional effect on chemotherapy-resistant breast cancer cells observed in the current study indicates that high-dose vitamin $\mathrm{C}$ has a selective and independent anti-proliferative effect on breast cancer. Since most advanced breast cancers ultimately develop resistance to conventional anti-cancer therapies, high-dose vitamin $\mathrm{C}$ could be a new strategy for overcoming such resistance.

Additional studies on high-dose vitamin $\mathrm{C}$ therapy from the real-world clinical applications are needed before the exact mechanism or optimal dose of vitamin $\mathrm{C}$ therapy is determined.

In conclusion, based on previous reports that high-dose vitamin $\mathrm{C}$ exerts anti-tumorigenic activity by increasing the amount of ROS in cancer cells without meaningful toxicities to normal cells, the current study confirmed the in vitro anticancer activity of high-dose vitamin $\mathrm{C}$ and demonstrated a similar efficacy in treatment-resistant breast cancer cells. Furthermore, an additive anti-cancer effect when combined with conventional agents was also observed in the current study, offering important evidence that high-dose vitamin $\mathrm{C}$ is a promising therapeutic drug, especially when considering that patients with advanced breast cancer ultimately develop resistance to conventional agents. Therefore, further clinical trials are warranted to determine the additive effect of highdose vitamin $\mathrm{C}$ in patients with advanced breast cancer.

\section{Conflicts of Interest}

The Authors declare that they have no financial or non-financial competing interests.

\section{Acknowledgements}

The Authors would like to thank Dr. Richard J. Santen (University of Virginia Health System, Charlottesville, VA, USA) for providing tamoxifen-resistant MCF-7 cells (TRAM-R) and long-term estrogen-deprived MCF-7 cells (LTED). This study was supported by a grant from the National R\&D Program for Cancer Control, Ministry of Health and Welfare, Republic of Korea (1420040) and a National Research Foundation (NRF) grant funded by the Korean Government (2014R1A5A2009242).

\section{References}

1 Ferlay J, Soerjomataram I, Dikshit R, Eser S, Mathers C, Rebelo M, Parkin DM, Forman D and Bray F: Cancer incidence and mortality worldwide: Sources, methods and major patterns in globocan 2012. Int J Cancer 136(5): E359-386, 2015. 
2 Jacobs HJ, van Dijck JA, de Kleijn EM, Kiemeney LA and Verbeek AL: Routine follow-up examinations in breast cancer patients have minimal impact on life expectancy: A simulation study. Ann Oncol 12(8): 1107-1113, 2001.

3 Padayatty SJ, Sun AY, Chen Q, Espey MG, Drisko J and Levine M: Vitamin c: Intravenous use by complementary and alternative medicine practitioners and adverse effects. PLoS One 5(7): e11414, 2010.

4 Moertel CG, Fleming TR, Creagan ET, Rubin J, O'Connell MJ and Ames MM: High-dose vitamin c versus placebo in the treatment of patients with advanced cancer who have had no prior chemotherapy. A randomized double-blind comparison. $\mathrm{N}$ Engl J Med 312(3): 137-141, 1985.

5 Creagan ET, Moertel CG, O'Fallon JR, Schutt AJ, O'Connell MJ, Rubin $J$ and Frytak S: Failure of high-dose vitamin c (ascorbic acid) therapy to benefit patients with advanced cancer. A controlled trial. N Engl J Med 301(13): 687-690, 1979.

6 Yang G, Yan Y, Ma Y and Yang Y: Vitamin $\mathrm{c}$ at high concentrations induces cytotoxicity in malignant melanoma but promotes tumor growth at low concentrations. Mol Carcinog 56(8): 1965-1976, 2017

7 Nagappan A, Park KI, Park HS, Kim JA, Hong GE, Kang SR, Lee DH, Kim EH, Lee WS, Won CK and Kim GS: Vitamin c induces apoptosis in ags cells by down-regulation of 14-33 sigma via a mitochondrial dependent pathway. Food Chem 135(3): 1920-1928, 2012.

8 Kim JE, Kang JS and Lee WJ: Vitamin c induces apoptosis in human colon cancer cell line, hct- 8 via the modulation of calcium influx in endoplasmic reticulum and the dissociation of bad from 14-3-3beta. Immune Netw 12(5): 189-195, 2012.

9 Hong SW, Jin DH, Hahm ES, Yim SH, Lim JS, Kim KI, Yang Y, Lee SS, Kang JS, Lee WJ, Lee WK and Lee MS: Ascorbate (vitamin c) induces cell death through the apoptosis-inducing factor in human breast cancer cells. Oncol Rep 18(4): 811-815, 2007

10 Fritz H, Flower G, Weeks L, Cooley K, Callachan M, McGowan J, Skidmore B, Kirchner L and Seely D: Intravenous vitamin c and cancer: A systematic review. Integr Cancer Ther 13(4): 280300,2014

11 Padayatty SJ, Sun H, Wang Y, Riordan HD, Hewitt SM, Katz A, Wesley RA and Levine M: Vitamin c pharmacokinetics: Implications for oral and intravenous use. Ann Intern Med 140(7): 533-537, 2004

12 Chen Q, Espey MG, Krishna MC, Mitchell JB, Corpe CP, Buettner GR, Shacter E and Levine M: Pharmacologic ascorbic acid concentrations selectively kill cancer cells: Action as a prodrug to deliver hydrogen peroxide to tissues. Proc Natl Acad Sci USA 102(38): 13604-13609, 2005.

13 Ohno S, Ohno Y, Suzuki N, Soma G and Inoue M: High-dose vitamin c (ascorbic acid) therapy in the treatment of patients with advanced cancer. Anticancer Res 29(3): 809-815, 2009.

14 Frei B and Lawson S: Vitamin c and cancer revisited. Proc Natl Acad Sci USA 105(32): 11037-11038, 2008.

15 Vera JC, Rivas CI, Fischbarg J and Golde DW: Mammalian facilitative hexose transporters mediate the transport of dehydroascorbic acid. Nature 364(6432): 79-82, 1993.
16 Tsukaguchi H, Tokui T, Mackenzie B, Berger UV, Chen XZ, Wang Y, Brubaker RF and Hediger MA: A family of mammalian nat-dependent 1-ascorbic acid transporters. Nature 399(6731): 70-75, 1999.

17 Buettner GR and Jurkiewicz BA: Catalytic metals, ascorbate and free radicals: Combinations to avoid. Radiat Res 145(5): 532$541,1996$.

18 McCarty MF, Barroso-Aranda J and Contreras F: Oxidative stress therapy for solid tumors - a proposal. Med Hypotheses 74(6): 1052-1054, 2010.

19 Szatrowski TP and Nathan CF: Production of large amounts of hydrogen peroxide by human tumor cells. Cancer Res 51(3): 794-798, 1991

20 Padayatty SJ, Riordan HD, Hewitt SM, Katz A, Hoffer LJ and Levine M: Intravenously administered vitamin $\mathrm{c}$ as cancer therapy: Three cases. CMAJ 174(7): 937-942, 2006.

21 Block KI, Koch AC, Mead MN, Tothy PK, Newman RA and Gyllenhaal C: Impact of antioxidant supplementation on chemotherapeutic efficacy: A systematic review of the evidence from randomized controlled trials. Cancer Treat Rev 33(5): 407418, 2007.

22 Hoffer LJ, Levine M, Assouline S, Melnychuk D, Padayatty SJ, Rosadiuk K, Rousseau C, Robitaille L and Miller WH Jr.: Phase i clinical trial of i.V. Ascorbic acid in advanced malignancy. Ann Oncol 19(11): 1969-1974, 2008.

23 Hoffer LJ, Robitaille L, Zakarian R, Melnychuk D, Kavan P, Agulnik J, Cohen V, Small D and Miller WH Jr.: High-dose intravenous vitamin c combined with cytotoxic chemotherapy in patients with advanced cancer: A phase i-ii clinical trial. PLoS One 10(4): e0120228, 2015.

24 Cameron E and Pauling L: Supplemental ascorbate in the supportive treatment of cancer: Reevaluation of prolongation of survival times in terminal human cancer. Proc Natl Acad Sci USA 75(9): 4538-4542, 1978.

25 Cameron E and Pauling L: Supplemental ascorbate in the supportive treatment of cancer: Prolongation of survival times in terminal human cancer. Proc Natl Acad Sci USA 73(10): 3685-3689, 1976.

26 Prasad KN, Hernandez C, Edwards-Prasad J, Nelson J, Borus T and Robinson WA: Modification of the effect of tamoxifen, cisplatin, dtic, and interferon-alpha $2 \mathrm{~b}$ on human melanoma cells in culture by a mixture of vitamins. Nutr Cancer 22(3): 233-245, 1994.

27 Kurbacher CM, Wagner U, Kolster B, Andreotti PE, Krebs D and Bruckner HW: Ascorbic acid (vitamin c) improves the antineoplastic activity of doxorubicin, cisplatin, and paclitaxel in human breast carcinoma cells in vitro. Cancer Lett 103(2): 183-189, 1996.

28 Taper HS, de Gerlache J, Lans M and Roberfroid M: Non-toxic potentiation of cancer chemotherapy by combined $\mathrm{c}$ and $\mathrm{k} 3$ vitamin pre-treatment. Int J Cancer 40(4): 575-579, 1987.

Received October 1, 2018

Revised January 5, 2019

Accepted January 7, 2019 